\title{
COLLATERAL ESTOPPEL EFFECT OF STATE COURT JUDGMENT IN FEDERAL ANTITRUST SUITS
}

The federal courts are granted exclusive jurisdiction over civil suits brought pursuant to the antitrust laws. ${ }^{1}$ While state courts are thereby precluded from adjudicating antitrust suits, a state court hearing a case properly within its jurisdiction may be called upon to determine whether a party to the suit has violated the antitrust laws, as for example, where illegality is raised as a defense to a suit for breach of contract. ${ }^{2}$ This raises the question of whether a finding by the state court on an issue which, if brought affirmatively, would not be within its jurisdiction, is conclusive in a subsequent treble damage suit brought in a federal court. Ordinarily, the doctrine of collateral estoppel would apply, preventing relitigation of matters previously determined in a prior action between the same parties. ${ }^{3}$ Two well-established policies are thus brought into confict: the exclusive jurisdiction of the federal courts on one hand, and finality of litigation on the other. This Comment is an attempt to explore the problem witl primary emphasis on the civil antitrust action for treble damages, although it will be necessary to examine the practice in other areas of the law in which the jurisdiction of the federal courts is exclusive. ${ }^{4}$

${ }^{I}$ Clayton Act $\S 4,38$ Stat. 731 (1914), 15 U.S.C. $\$ 15$ (1958).

2 The state court is permitted to hear the antitrust question when it is merely incidental to the cause of action brought under its general jurisdiction. See note 6 infra and accompanying text.

${ }^{3}$ Collateral estoppel is but a part of a general policy against the rehitigation of matters determined in a prior suit. The doctrine of "res judicata" operates to preclude subsequent litigation on the same "cause of action." If in the first suit the plaintiff is the victor, his cause of action is said to be "merged in the judgment." RestateMrent, JudGMrents $\$ 47$ (1942). Similarly, if in the first action judgment is for the defendant, the cause of action is said to be "barred" by the judgment. Id. at $\$ 48$. The primary difficulty is, of course, the determination of what constitutes a "cause of action." See Developments in the Law-Res Judicata, 65 HARv. L. REv. 818, 824-31 (1952).

Where a subsequent action is brought based upon a different cause of action, matters which have been actually hitigated and determined in the prior action cannot be relitigated; in such cases the preclusion is based upon the doctrine of "collateral estoppel." REsTATEMENT, JUDGMIENTS $\S 68$. See, e.g., Stoll v. Gottlieb, 305 U.S. 165 (1938); Cromwell v. County of Sac, 94 U.S. 351, 353 (1876). See generally Scott, Collateral Estoppel by Judgment, 56 Harv. L. Rev. 1 (1942). Note that, unlike merger and bar, only matters which were actually hitigated can be given estoppel effect. Moreover, several rules have been developed to insure that the adjudication upon which the estoppel is based was actual and vigorous. See notes 68 and 87 infra.

4 There are a number of distinguishable, but related problems, the analysis of which is beyond the scope of this Comment. Among them are:

(1) The preclusive effect of an administrative finding in a subsequent antitrust action. In United States v. RCA, 358 U.S. 334 (1959), it was argued that the FCC, in approving an exchange of radio stations, bad passed on the question of whether or not the exchange was in violation of the antitrust laws, and that this determination was conclusive in a subsequent antitrust suit brought by the government. The Court rejected this argument on the ground that the FCC did not have the power to decide the antitrust question as such, and since there was no valid determination, the government was not precluded by collateral estoppel from maintaining the action.

(2) The effect of a state court judgment in a subsequent administrative proceeding, where the jurisdiction of the administrative body is exclusive. See NLRB v. Thayer Co., 213 F.2d 748, 754 (1st Cir. 1954) ; Meltzer, The Supreme Court, Congress, and State Jurisdiction over Labor Relations: I, 59 Coluas. L. REv. 6, 35 n.112 (1959). Cf. Aaron, Arbitration in the Federal Courts: Aftermatin of the Triology, 9 U.C.L.A.L. REv. 360, 368-71 (1962).

(3) The effect to be given a state court judgment in subsequent tax litigation. See Braverman \& Gerson, The Conclusiveness of State Court Decrees in Federal Tax Litigation, 17 TAx L. REv. 545 (1962). 


\section{THE DOCTRINE OF Lyons v. Westinghouse}

The leading case involving the application of collateral estoppel in antitrust litigation is Lyons v. Westinghouse Elec. Corp. ${ }^{5}$ Westinghouse sued Lyons, its agent for the sale of lamps, in a New York state court, demanding an accounting of funds received in the sale of lamps given Lyons on consignment. Lyons defended affirmatively on the ground of illegality, alleging that Westinghouse and General Electric had engaged in a conspiracy in restraint of the marketing and sale of electric bulbs. ${ }^{6}$ The state court found for Westinghouse, and Lyons appealed. While the appeal was pending, Lyons brought an antitrust action for treble damages pursuant to Section 4 of the Clayton Act. ${ }^{7}$ The complaint in the federal court action was nearly identical ${ }^{8}$ to the defenses raised in the earlier state court action. Westinghouse moved for and was granted a stay in the antitrust proceedings. ${ }^{9}$ The Court of Appeals for the Second Circuit, per Judge Learned Hand, ordered the stay vacated, holding that the findings of the state court as to the alleged antitrust violation would not prevent the parties from relitigating the matter in the federal court. Even though traditional concepts would preclude a second litigation of the antitrust claim, the majority felt it necessary to immunize the federal court from the otherwise binding determinations of state courts in such cases in order to preserve the integrity of the grant of exclusive jurisdiction. Stating that collateral estoppel was at best a compromise between conflicting interests, the court noted that the action for treble damages is

part of the effort to prevent monopoly and restraints of commerce; and it was natural to wish it to be uniformly administered, being national in scope. . . Obviously, an administration of the Acts, at once effective and umiform, would best be accomplished by an untrammeled jurisdiction of the federal courts. 10

Although the language of the decision appears to create an absolute immunity from state court determinations, the scope of immunity was narrowed by Judge Learned Hand ${ }^{11}$ who, in denying a petition for rehearing, ${ }^{12}$ distinguished a United States Supreme Court case, Becker v. Contoure Laboratories, ${ }^{13}$ which seemingly

5222 F.2d 184 (2d Cir.), cert. denied, 350 U.S. 825 (1955).

6 That the state courts might hear such a defense, the subject matter of which, if asserted affirmatively, could only be hitigated in the federal courts, was decided in Pratt v. Paris Gas Light \& Coke Co., 168 U.S. 255 (1897).

738 Stat. 731 (1914), 15 U.S.C. § 15 (1958):

Any person who shall be injured in his busmess or property by reason of anything forbidden in the antitrust laws may sue therefor in any district court of the United States ... . without respect to the amount in controversy, and shall recover threefold the damages by him sustained ....

8222 F.2d at 186 .

8 Lyons v. Westinghouse Elec. Corp., 16 F.R.D. 384 (S.D.N.Y. 1954). The trial judge felt that there was a "reasonable likelihood that the conclusion of the State proceeding will make it unnecessary to try the action here." $1 d$. at 385.

10222 F.2d at 189. Lyons was noted extensively. See 55 ColvM. L. REv. 1078 (1955); 69 HARv. L. REv. 573 (1956); 40 MINN. L. REv. 618 (1956); 31 N.Y.U.L. REv. 955 (1956); Comment, 50 Nw. U.I. Rev. 788 (1956); Comment, 8 StaN. L. REv. 439 (1956).

11 Judge Hand noted that the other judge who concurred in denying the rehearing, Judge Dimock, did not agree on this poimt. The narrowed view of immunity, then, was Judge Hand's alone.

12222 F.2d at 196.

13279 U.S. 388 (1929). The Court held that a factual determination of a state court was conclusive in a subsequent suit for infringement, even though the result would render "an important patent . . void." Id. at 392. See notes $23-25$ infra and accompanying text. 
had reached the opposite conclusion. That case, he explained, required only that "specific findings of fact of the state court"14 be given estoppel effect; the findings of the state court in Lyons, however, were expressed as a general conclusion of law and fact ${ }^{15}$ which could not be permitted to bind the federal court in the antitrust proceeding.

Prior to Lyons $v$. Westinghouse, the decisions concerning the relationship of state court determinations to subsequent federal antitrust actions were, generally, of a cursory nature; ${ }^{18}$ the discussion in Lyons appears to be the first thoughtful consideration of the problem.

The most recent treatment of the question was in Mach-Tronics, Inc. v. Zirpoli. ${ }^{17}$ The first action was brought in a state court by Ampex against MachTronics for unfair competition, breach of confidential relationship, and wrongful appropriation of trade secrets. Mach-Tronics denied the allegations of the complaint, and as a separate affirmative defense, alleged that Ampex had unlawfully conspired to restrain trade. ${ }^{18}$ The second action was instituted by Mach-Tronics in a federal court, alleging violation of Sections 1 and 2 of the Sherman Act, ${ }^{19}$ with plaintiff demanding treble damages. At the request of Ampex, the antitrust proceedings were stayed pending final determination of the state court action. Straddling the collateral estoppel issue, the Court of Appeals for the Ninth Circuit held that whether or not final judgment by the state court would work an estoppel, the stay was improperly granted. If the state court's determination would not be binding in the pending antitrust action, then staying the federal proceedings could serve no useful purpose. Conversely, if an estoppel would be raised, then the antitrust action should be permitted to proceed with dispatch:

It would seem to us to be uuthinkable that a federal court having exclusive jurisdiction of a treble damage antitrust suit would tie its own hands by a stay of this kind in order to permit a judge of a state court, without a jury, to make a determination which would rob the federal court of full power to determine all of the fact issues before it. ${ }^{20}$

In Mach-Tronics, in contrast with Lyons v. Westinghouse, the state court action was pending, and thus no findings had been made. The federal court could,

14222 F.2d at 196 (dictum) (emphasis added).

15 "Finally, the third defense of illegahty based upon violation of the anti-trust laws, has neither been sustained nor established." Westinghouse Elec. Corp. v. Lyons, 125 N.Y.S.2d 420, 423 (Sup. Ct. 1953).

10 E.g., Singer v. Hollander, 202 F.2d 55 (3d Cir. 1953) ; Red Rock Cola Co. v. Red Rock Bottlers, 165 F.2d 406 (5th Cir. 1952) (state court determination binding on federal court if fully litigated on the inerits) ; Strauss v. American Publishers' Ass'n, 201 Fed. 306 (2d Cir. 1912) (expressly overruled in Lyons v. Westinghouse Elec. Corp., 222 F.2d 184, 195 (2d Cir. 1955)).

17316 F.2d 820 (9th Cir. 1963) (alternative holding).

18 Id. at 823 .

1926 Stat. 209 (1890), as amended, 15 U.S.C. $\S \S 1-2$ (1958).

$20316 \mathrm{~F} .2 \mathrm{~d}$ at 833 . It is important to distinguish the separate questions here: (1) should the state court findings be given estoppel effect and (2) if so, should the federal court stay its proceedings? The concern bere is with the first of these. As to the second, it would appear that the Mach-Tronics court is correct in stating that as long as the state findings will preclude rehitigation, the federal court ought to proceed. "Although the court's holding [in Lyons $v$. Westinghouse] on the binding effect of the state court judgment seems questionable, it would seem that where exclusive jurisdiction has been conferred on the federal courts they should be inore reluctant to grant a stay, which has the effect of permitting a state court judgment to have a collateral estoppel effect in the federal action." Note, Stay of Federal Proceedings in Deference to Concurrently Pending State Court Suits, 60 CoLuM. L. Rev. 684, 700 (1960). 
therefore, only speculate as to whether they would be pure determinations of fact, or a mixture of law and fact. Under the narrowed rule of Lyons, only the former could work an estoppel. As a result, the decision neither adopts nor rejects Judge Hand's dictum..$^{21}$

\section{ANALOGOUS AREAS}

The rejection of collateral estoppel in Lyons v. Westinghouse constitutes a departure from traditional views as to the conclusive effect of judgments rendered in a prior action, although such a course had been advocated by a number of authorities. ${ }^{22}$ In other areas in which the federal courts have been given exclusive subject matter jurisdiction, the approaches taken have been varied. An examination of some of these follows.

\section{A. Patent Cases}

In Becher v. Contoure Laboratories, ${ }^{23}$ the United States Supreme Court passed on the question of the preclusive effect to be given prior state court judgments in patent infringement suits. The first action, brought in a New York state court by one Oppenheimer, determined that his former employee, Becher, in violation of a confidential relationship, had patented a machine which Oppenheimer himself had invented. In that action, Oppenheimer received a money judgment. Becher then sued Oppenheimer's corporate assignee for infringement of his patent. Although the Court recognized that only federal courts have jurisdiction to determine the validity of patents, ${ }^{24}$ it nevertheless held that the state court's finding that the true inventor was Oppenheimer and that Becher, in patenting the device, had violated a confidential relationship, was conclusive in the second action. On the basis of the state court's findings in the earlier action, the federal court denied Becher a remedy for the alleged infringement of his patent. ${ }^{25}$

Following Becher, other courts reached the same result, ${ }^{26}$ frequently with little discussion of the conflicting policies of collateral estoppel and exclusive jurisdiction. ${ }^{27}$ These cases generally involved state court decisions on questions of "state

21 See notes 11-15 supra and accompanying text.

22 See, e.g., RESTATEMIENT, JUdGMENTS \& 71 (1942); Scott, supra note 3 at 19.

23279 U.S. 388 (1929).

2428 U.S.C. §1338(a) (1958):

The district courts shall have original jurisdiction of any civil action arising under any Act of Congress relating to patents, copyrights, and trade-marks. Such jurisdiction shall he exclusive of the courts of the states in patent and copyright cases.

25 Holmes, J.:

That decrees validating or invalidating patents belong to the Courts of the United States does not give sacrosanctity to facts that may be conclusive upon the question in issue. A fact is not prevented from being proved in any case in which it is material, by the suggestion that if it is true an important patent is void ....

279 U.S. at 391-92.

20 E.g., Nelson v. Swing-A-Way Mfg. Co., 266 F.2d 184 (8th Cir. 1959) (state court determination of patent ownership collaterally estops losing party from claiming patent infringement in subsequent federal court action); Talbot v. Quaker-State Oil Ref. Co., 104 F.2d 967 (3d Cir. 1939) (state court finding that the holder of a patcnt had issued a license to defendant precluded a subsequent suit for infringement); Zachs v. Aronson, 49 F. Supp. 696 (D. Conn. 1943); Cavicchi v. Mohawk Mfg. Co., 34 F. Supp. 852 (S.D.N.Y. 1940) (alternative holding).

27 See, e.g., Talbot v. Quaker-State Oil Ref. Co., supra note 26. 
law," usually problems relating to licensing agreements, assignment of the patent, and other questions of contract. In Vanderveer v. Erie Malleable Iron Co. ${ }^{28}$ however, the state court was called upon to determine the scope of plaintiff's patent. Plaintiff, holder of a patent, sued his licensee for royalties allegedly due him under the terms of their contract. The defense to this action was that the product made by the defendant was not within the scope of the patent. ${ }^{29}$ In a subsequent suit for patent infringement, the state court finding ${ }^{30}$ that defendant's product was not within the scope of plaintiff's patent was held to work an estoppel. Pointing to a line of cases giving estoppel effect to state court determinations, ${ }^{31}$ the Court of Appeals for the Third Circuit held that the prior finding precluded a suit for infringement. Vanderveer constituted a significant departure from earlier decisions $^{32}$ in that the question determined by the state court-the scope of a patent -is one normally reserved for adjudication in federal courts.

The court rejected the contention that, although pure determinations of fact might form the basis for an estoppel, a mixed conclusion of law and fact could not bind a federal court exercising its exclusive subject matter jurisrdiction:

It may be conceded that the question of construing the clains of a patent is one of law in the sense that, as in the case of other integrated documents, it is a question for the court and not the jury. But the question of infringement also involves questions of fact, such as the nature of the devices alleged to infringe and whether in fact they are within the patent claims as the court has construed them. Thus the finding of infringement is a finding of fact, of the type sometimes called a conclusion of ultimate fact, as to which the doctrine of res judicata is applicable..$^{33}$

Significantly, the argument thus rejected was the very basis for Judge Hand's distinguishing Becher v. Contoure Laboratories. Moreover, the court in Vanderveer rejected the formulation of the Restatement of Judgments, ${ }^{34}$ which it characterized as contrary to the Supreme Court's pronouncement in Becher v. Contoure Laboratories and "primarily directed to cases involving title to land in another state. ${ }^{135}$ On the other hand, the decision in Lyons v. Westinghouse had rested in part on the position of the Restatement. ${ }^{36}$ Clearly, the courts in Lyons and in Vanderveer have chosen differing solutions to the problem. ${ }^{37}$

28238 F.2d 510 (3d Cir. 1956), cert. deried, 353 U.S. 937 (1957).

29 While the grant of exclusive jurisdiction would preclude adjudication of this question if brought directly in a state court, its jurisdiction clearly includes actions on a contract. It has been held that the state court may properly decide such a question where it has been raised, as here, incidentally to an action properly within the state court's jurisdiction. Pratt v. Paris Gas Light \& Coke Co., 168 U.S. 255 (1897).

30 Vanderveer v. Erie Malleable Iron Co., 384 Pa. 12, 119 A.2d 204 (1956).

31 See cases cited at note 26 supra.

32 Ibid.

33238 F.2d at 514.

34 REstatedent, JUdgMENTs $\$ 71$ (1942):

Where a court lias incidentally determined a matter which it would have had no jurisdiction to determine in an action brought directly to determine it, the judgment is not conclusive in a subsequent action to determine the matter directly.

35238 F.2d at 515 . This is not entirely true. Only comment $b$ deals with title to Iand in another state. Comment $c$ suggests that a state court determination of the validity of a patent should not be binding on a subsequent action in federal court. See also comments $d$ (courts of limited subject matter jurisdiction) and $e$ (matters affecting status).

38 See 222 F.2d at 190.

3728 U.S.C. $\$ 1338($ a) (1958), quoted at note 24 supra, which grants exclusive jurisdiction to the federal courts in patent cases, makes an identical grant in copyriglt actions. Only one case has been found dealing with the question of estoppel: Simon \& Schuster, Inc. v. Cove 


\section{B. Admiralty: Limitation of Liability}

Although the federal courts are granted exclusive civil jurisdiction in admiralty cases ${ }^{38}$ the "saving to suitors" clause ${ }^{39}$ preserves the right of a common law remedy; thus a potential claimant may, at his option, bring his suit in a state court where a "common law remedy" is available.

However, some types of actions are peculiar to admiralty, there being no common law remedy. One of these is the proceeding to limit liability, ${ }^{40}$ in which the owner of a ship may petition a court of admiralty to limit his liability to the value of the ship. ${ }^{41}$ All potential claimants are brought into the proceeding, ${ }^{42}$ and the right of petitioner to limit his liability is determined. This right is conditioned on the absence of the shipowner's "privity or knowledge," 43 that is, absence of actual knowledge of the fault which occasioned the loss. At the same time, pursuant to the "saving to suitors" clause, actions may be brought against the owner in state courts. The Limitation of Liability Act permits the admiralty court to enjoin the

Vitamin and Pharm., Inc., 211 F. Supp. 72 (S.D.N.Y. 1962) (alternative grounds). This case is decidedly uncertain in its holding; it arose in a procedural context similar to Lyons: the defendants in the federal court action moved for a stay on the ground that an action in the state court, which they had instituted, would dispose of the fact issues to be adjudicated in the federal action. The court denied the stay, suggesting three grounds for its decision: (1) the finding of the state court might not be a complete defense to the federal action; (2) two of the plaintiffs in the federal court were not parties to the state court action; (3) because the copyright jurisdiction is exclusive, the rule of the Lyons case might apply, preventing the use of the state court decision as an estoppel. It seems clear that the rule as to copyright cases is yet an open question.

3828 U.S.C. $\$ 1333$ (1958).

39 Judiciary Act of $1789 \S 9,1$ Stat. 76-77:

[T] he district courts ... shall also have exclusive original cognizance of all civil causes of admiralty jurisdiction . . . saving to suitors, in all cases, the right of a common law remedy, where the common law is competent to give it . . . .

This has been carried over, with only sligbt modification, into 28 U.S.C. $\$ 1333$ (1958).

40 Limitation of Liability Act, 9 Stat. 635 (1851), 46 U.S.C. $\$$ 181-89 (1958). See generally, GIIMORE \& BIACK, ADMTRALTY, ch. 10 (1957). Actually until, 1936 the act was silent on the question of jurisdiction but Norvich Co. v. Wright, 80 U.S. (13 Wall.) 104 (1892) settled the matter:

Now, no court is better adapted than a court of admiralty to administer precisely such relief [himitation of liability]. It happens every day that the procceds of a vessel, or other fund, is brought into that court to be distributed amongst those whom it may concern. Claimants are called in by monition to present and substantiate their respective claims; and the fund is divided and distributed according to the respective hens and rights of all the parties .... . It is . . . evident that the state courts have not the requisite jurisdiction. . . . We have no doubt that the District Courts, as courts of admiralty and maritime juristictions, have jurisdiction of the matter .....

Id. at 123-24 (emphasis added). The Court also asserted the right to make "all needful rules and regulations for facilitating the course of procecding," Ibid. These were issued in 80 U.S. (13 Wall.) xii as "Supplementary Rules of Practice in Admiralty," and the appropriate forum was therein made the district court sitting in admiralty. With only minor change, these now appear as Admiralty Rules 51-55. The Limitation Act now includes a codification of the former practice as to jurisdiction. See 49 Stat. 1480 (1936), 46 U.S.C. $\$ 185$ (1958).

41 The benefit to a shipowner of such a procedure is greatest where the ship bas been damaged or destroyed, for his liability may be limited to the diminished value. GuMORE \& BIACK, op. cit. supra note 40 at $\$ 10-1$.

42 GIMMORE \& BLACK, op. cit. supra note 40 at $\$ 10-17$.

43 Limitation of Liability Act $\$ 3,9$ Stat. 635 , (1851), as amended, 46 U.S.C. $\$ \S 183$ (a), (e) (1958). 
state actions ${ }^{44}$ in order to facilitate the simultaneous adjudication of multiple claims, but where the aggregate of claims does not exceed the value of the ship, or where there is but a single claimant, the state court proceeding will be permitted to continue..$^{45}$ In the course of the state action, generally founded on a claim of negligence, issues pertaining to the shipowner's "privity or knowledge" may be litigated. ${ }^{46}$ Here, then, is a situation analogous to that in Lyons $v$. Westinghouse: a strong policy favoring exclusive jurisdiction in the federal admiralty courts on the one hand, and the traditional concepts underlying the doctrine of collateral estoppel on the other. The federal admiralty courts have attempted to resolve this conflict by developing a procedure quite unlike that chosen in either the antitrust or the patent cases. The state court action is permitted to proceed, thus giving effect to the "saving to suitors" clause; the federal court retains, however, "as a matter of precaution," shipowner-defendant, in the state court action, can raise the defense of the pending limitation proceeding, ${ }^{48}$ and thereby preserve his right to linit liability to the value of the ship. Before permitting the state court action to proceed, the federal admiralty court will require the claimant to stipulate that, as to the question of the shipowner's right to limit his liability, any findings of the state court will not be claimed as res judicata, or to work an estoppel. ${ }^{49}$ In the absence of a stipulation to this effect, the admiralty court will enjoin the state proceeding. ${ }^{50}$

This procedure is undeniably a workable solution, preserving the integrity of the exclusive jurisdiction given the federal admiralty courts in limitation proceedings, without intruding upon the policy of the "saving to suitors" clause. Such a course is apparently not open to federal courts in the absence of express statutory authority to enjoin state court proceedings; ${ }^{51}$ to reach the same result, the court

4449 Stat. 1480 (1936), 46 U.S.C. $§ 185$ (1958) provides that, on the shipowner's compliance with the statutory requirements, "all claims and proceedings against the owner with respect to the matter in question shall cease." This presents an "obvious conflict" with the policy of the "saving to suitors" clause. Grcmore \& BrACK, op. cit. supra note 40, \$10-16.

45 GIMORE \& BLACK, op. cit. supra note 40 at $\$ 10-18$.

46 The relationship between the owner's "privity or knowledge" of the defect causing the loss and his "negligence" is obvious. Therefore, the action in a state court, while founded on negligence, may well determine questions of fact which strongly bear on the admiralty court's inquiry as to privity and knowledge.

47 Langnes v. Green, 282 U.S. 531, 542 (1931).

48 Id. at 543.

49 Petition of Red Star Barge Line, Inc., 160 F.2d 436 (2d Cir.), cert. denied, 331 U.S. 850 (1947). See also Waldie Towing Co., Inc. v. Ricca, 227 F.2d 900 (2d Cir. 1955). Cf. Petition of Spearin, Preston \& Burrows, Inc., 190 F.2d 684 (2d Cir. 1951); Great Lakes Dredge \& Dock Co. v. Lynch, 173 F.2d 281 (6th Cir. 1949); In re Trawler Gudrun, Inc., 101 F. Supp. 586

(D. Mass. 1951) ; Petition of M.P. Howlett, Inc., 75 F. Supp. 438 (E.D.N.Y.1948).

50 Accord, Ex Parte Green, 286 U.S. 437 (1932).

51 The general rule prohibits federal courts from enjoining state court proceedings:

A court of the United States may not grant an injunction to stay proceedings in a

State court except as expressly authorized by Act of Congress, or where necessary in aid of its jurisdiction, or to protect or effectuate its judginents.

28 U.S.C. $\$ 2283$ (1958) (emphasis added). Thus a federal court may properly enjoin a state proceeding in which the federal court has exclusive subject matter jurisdiction in cases where the state court lacks proper jurisdiction. 1a MOORE, Federal Practice $\llbracket 0.208$ [4], at 2325 (2d ed. 1961). But where the state court properly has jurisdiction over the action, the fact that the federal court is hearing a case in exercise of its exclusive jurisdiction does not permit the federal court to enjoin such state actions which are also within the compass of the federal action. Red Rock Cola Co. v. Red Rock Bottlers, 195 F.2d 406 (2d Cir. 1952). Thus in Lyons, 
in Lyons v. Westinghouse found it necessary to reject the application of collateral estoppel. In the limitation cases, the courts have assumed that collateral estoppel would apply in the absence of the required stipulation by the state court plaintiff. ${ }^{52}$ Whether the federal admiralty courts, in the absence of the power to enjoin actions brought in state courts, would have adopted a rule similar to that of Lyons v. Westinghouse is open to speculation. Of greater importance is the fact that federal immunity from prejudgment by state courts is not entirely without judicial precedent.

\section{Actions Under SEC Rule 10b-5}

Section 10(b) of the Securities Exchange Act and SEC Rule 10b-5 adopted in pursuance thereof, prohibit the use of deceptive devices in connction with the purchase and sale of securities. ${ }^{53}$ Rule $10 \mathrm{~b}-5$ has been found to impose a duty of disclosure $^{54}$ and, although the rule makes no provision for a private remedy, the courts have implied one. ${ }^{55}$ Suits brought under the act are exclusively within the

the federal court was not permitted to enjoin the state action, even though there was a threat that the state court's findings would subsequently affect the federal court's exercise of its exclusive jurisdiction. Lyons v. Westinghouse Elec. Corp., 201 F.2d 510 (2d Cir. 1953).

As was noted in note 44 supra, the admiralty court hearing a petition to limit liability inay enjoin the state court proceeding as a result of the authorization of the Limitation Act. The prohibition of 28 U.S.C. $\$ 2283$ does not, therefore, apply since the power to enjoin was "expressly authorized by Act of Congress."

52 See Petition of Red Star Barge Line, Inc., 160 F.2d 436 (2d Cir.), cert. dentied, 331 U.S. 850 (1947):

If, for example, in support of the charge of negligence, the appellee should adduce evidence that the appellants' officers had seen the defects in the coalboat which are alleged to have contributed to the decedent's falling overhoard, the appellants' fear that a verdict for the plaintiff might be effective as an estoppel on the issue of their privity and knowledge. As a precaution against that possible danger, we think it would be reasonable and fair to all parties to require the appellee to file in the district court a statement that she waives any claim of res judicata relevant to the issue of himited hability and based on any judgment she might obtain in the state court action.

Id. at 438 .

53 Securities Exchange Act of $1934 \$ 10,48$ Stat. 891, 15 U.S.C. § 78j (1958):

It shall be unlawful for any person ... (b) to use or einploy, in connection with the purchase or sale of any security registered on a national securities exchange or any security not so registered, any manipulative or deceptive device or contrivance in contravention of such rules and regulations as the Counmission may prescribe as necessary or appropriate in the public interest or for the protection of investors.

Securities Exchange Commission Rule 10b-5, 17 C.F.R. \$240.10b-5 (1949):

It shall be unlawful for any person, directly or indirectly, by use of any means or instrumentality of interstate commerce, or of the unails, or of any facility of any national securities exchange,

(a) To employ any device, schene, or artifice to defraud,

(b) To make any untrue statement of a material fact or to omit to state a material fact necassary in order to make the statments unade, in the light of the circumstances under which they were made, not misleading, or

(c) To engage in any act, practice, or course of busmess which operntes or would operate as a fraud or deceit upon any person,

in connection with the purchase or sale of any security.

54 Kardon v. National Gypsum Co., 73 F. Supp. 798, 800 (E.D. Penn. 1947) ("The duty created is that of disclosure ....") See Comment, 59 YALE L.J. 1120, 1142-56 (1950).

55 See, e.g., cases collected, Comment, 59 Yaxe L.J. 1120, 1122 n.17 (1950); Kardon v.

National Gypsum Co., supra note 54. 
jurisdiction of the federal courts; ${ }^{56}$ these are in addition to "any and all rights and remedies which may exist at law or equity."

In Connelly v. Balkwill, , $^{58}$ an action was brought in an Ohio state court ${ }^{59}$ for damages allegedly incurred in the sale of plaintiff's stock. It was claimed that the defendant had fraudulently concealed material facts which, had they been disclosed to plaintiff, would have prompted him to demand a higher price for the securities. After a trial on the merits, judgment was entered for the defendant, the court finding that the concealed facts were immaterial and that as a result defendant was not responsible for plaintiff's loss. A second action was brought in a federal district court, this time based on an alleged violation of Rule 10b-5. Defendant's plea of res judicata was accepted over plaintiff's contention that a "new" cause of action was presented..$^{80}$

The federal court found that Ohio case law imposes a duty of disclosure which is "no less strict than the duties imposed by Rule X 10b-5." 61 Thus, although the bases for the actions differed, the cause of action in each was the same, and res judicata barred the second. Moreover, the court ruled, even if the causes of action were not identical, collateral estoppel would prevent relitigation of those issues determined in the first action, including the materiality of the undisclosed information. ${ }^{02}$

Connelly can readily be distinguished from the preceding cases in that the same party brought both actions, while in the others the defendant in the first was the plaintiff in the second. ${ }^{63}$ Although res judicata would not apply in the other cases, the court was able to find a clear case of bar in Connelly. The holding as to res judicata seems eminently reasonable notwithstanding the statutory grant of exclusive jurisdiction. The plaintiff, having chosen to pursue his remedy in a state court, should not be allowed to relitigate his riglit to recover under the same operative facts, particularly in view of the finding that the applicable law of both

56 Securities Exchange Act of 1934, § 27, 48 Stat. 902, as amended, 15 U.S.C. 78 aa (1958). 57 Securities Exchange Act of 1934, § 28, 48 Stat. 903, as amended, 15 U.S.C. 78bb (1958). 1960).

58174 F. Supp. 49 (N.D. Ohio 1959) (alternative holding), aff'd, 279 F.2d 685 (6th Cir.

E0 Connelly v. Balkwill, No. 24234, Ohio C.P., Lake County, June 25, 1957, aff'd, No. 519, Ohio Ct. App., 7th Dist., Sept. 15, 1954.

Bo Plaintiff claimed that he was not barred from bringing the second action because it was based on Rule 10b-5, whereas the prior action was grounded on Ohio state law.

61174 F. Supp. at 56. This conclusion has been questioned. Note, 69 Yale L.J. 606, 608 n.15 (1960). Whether or not the court's comparison of Ohio and federal law was correct is immaterial for the purposes of this analysis. Assuming that Ohio decisional law and Rule 10b-5 impose the same duty of disclosure, the problem at hand concerns what res judicata effect should be given the state court decision. If Ohio law provided a less stringent test, then an entirely different question would be presented. See note 64 infra.

02174 F. Supp. at 60-61. Interestingly, plaintiff conceded that collateral estoppel would apply to prevent relitigation of ultimate facts determined in the prior action, but contended that certain of the findings were not material, and moreover were mere conclusions of law and not ultimate fact. This contention was rejected. Ibid.

63 The one exception is Vanderveer v. Erie Malleable Iron Co., 238 F.2d 510 (3d Cir. 1956), cert. denied, 353 U.S. 937 (1957). There, unlike in Connelly, the causes of action were completely different: in the state court, the plaintiff sued to recover payments allegedly due him under a license agreement, and in the second action (having lost in the first), he sued for infringement of his patent. Res judicata, therefore, was inapplicable although collateral estoppel precluded rehitigation of issues determined in the first trial. 
forums is identical. ${ }^{84}$ This seems especially true since the plaintiff could apparently have brought his action in federal court at the outset, based on Rule 10b-5, and joined with it a claim under Ohio state law. ${ }^{65}$ This reasoning cannot be applied to situations in which the adversary roles of the parties are reversed in the second action. However, the court held, in the alternative, that collateral estoppel would also apply. An application of this holding would include those situations where the adversary roles of the parties are reversed in the second action, and as such is contrary to the approach taken in Lyons v. Westinghouse.

\section{III}

\section{ANALYSIS}

It has been demonstrated that the rule of immunity from state court prejudgment in antitrust cases first advanced in Lyons $v$. Westinghouse is an exception to the traditional approach to collateral estoppel in cases where the federal courts have exclusive jurisdiction. Thus, for patent cases, Rule $10 \mathrm{~b}-5$ cases, and, arguably, for limitation of liability proceedings ${ }^{66}$ (were it not for the stipulation exacted from the state court claimant), the prior findings of state courts will be conclusive in subsequent federal proceedings, notwithstanding the grant of exclusive subject matter jurisdiction. The rejection of collateral estoppel in Lyons $v$. Westinghouse reflects a determination that the policy underlying res judicata and collateral estoppel is secondary to the preservation of exclusive federal jurisdiction in the antitrust cases.

Res judicata and collateral estoppel are products of the notion that "litigation must come to an end." No party who has had his day in court should be permitted another opportunity to improve his position with regard to the same cause of action, or the same issue of fact. As the Umited States Supreme Court has phrased it, "There is no reason to expect that the second decision will be more satisfactory than the first." 67 This can be true only if the first action was vigorously litigated on the merits, with both parties being given an ample opportunity to present their case in its most favorable light. With respect to collateral estoppel, under traditional concepts should the first action not meet these standards, there will be no estoppel. ${ }^{68}$ Similarly, if issues pertaining to a violation of the antitrust laws are

64 But see Note, 69 YAIE L.J. 606, 611 (1960), criticizing the court's approach to res judicata, and suggesting that even where the duty to disclose under Ohio law differed from the duty under Rule $10 \mathrm{~b}-5$, the prior judgment should bar a subsequent action.

$65 I d$. at 612 . Where a case presents a substantial federal question, the court has jurisdiction to dispose of a nonfederal claim. Hurn v. Oursler, 289 U.S. 238 (1933). This is true even though the court finds against the plaintiff on the federal claim. United Mine Wkrs. of Ain. v. Meadow Creek Coal Co., 263 F.2d 52 (6th Cir.), cert. denied, 359 U.S. 1013 (1959). Sce 2 Moore, Federal Practice $\llbracket 206$ [5] (2d ed. 1962).

80 But see text accompanying note 52 supra.

67 Stoll v. Gottheb, 305 U.S. 165, 172 (1938).

68 There are numerous safeguards designed to insure that the prior action meets this standard, among which are the following:

(1) The facts determined in the first action must have been essential to the judgment. For example, automobiles driven by $A$ and $B$ respectively are in a collision. $A$ sues $B$ alleging that the collision was caused by the neghigence of $B$. The findings of fact are that the accident 
not likely to be adequately litigated in a state court, the findings from that action slould not be conclusive in a subsequent suit for treble damages brought in a federal court.

Litigation arising under the antitrust laws is uniquely complex. Suits for treble damages are frequently of extraordinary length, and the amount of factual evidence involved may be voluminous. ${ }^{69}$ Judges of the state courts, unfamiliar with the complex body of antitrust law and inexperienced in dealing with the overpowering quantity of evidence involved in such an action, are ill-equipped to make determinations which will have binding effect beyond the scope of the immediate action. Such a view casts no discredit on the courts of the states, but rather reflects only the particularly complex character of antitrust litigation and the greater expertise of federal judges in this area.

Moreover, state procedures are frequently unsuited for the burdensome antitrust case. Most significant in this area is discovery. Federal procedures include an elaborate discovery mechanism ${ }^{70}$ which, while serving as a model for similar provisions in more than one-half of the states, ${ }^{71}$ far outstrips the procedures available in those states which have not elected to follow the example of the Federal Rules. While discovery is decidedly inportant in nearly all types of litigation, it is virtually indispensable in antitrust cases owing to the difficult problems of obtaining the requisite evidence to sustain an antitrust claim.

The refusal to give estoppel effect to prior state court findings in antitrust cases can be reconciled with the traditional view of collateral estoppel since there is every reason to believe, in light of the foregoing, that the second decision will be more satisfactory than the first. ${ }^{72}$ Courts lave refused to apply collateral estoppel in instances where the first suit was brought in a court of limited jurisdiction. The general rule appears to be that, in deciding whether collateral estoppel is to apply, the competency of the court and the adequacy of its procedures are of nuajor significance. For example, determinations of courts of limited monetary jurisdiction, such as municipal courts, will be given estoppel effect in a subsequent proceeding; ${ }^{73}$ the findings of a sinall claims court, however, will not

was caused by the combined negligence of $A$ and $B$; judgment is entered for $B$. In a subsequent suit brought by $B$ against $A$, the prior finding that $B$ was negligent will not be given estoppel effect, since it was not essential to the first judgment. RESTATEMENT, JUDGMIENTS $\$ 68$, comment o (1942). See also Cambria v. Jeffrey, 307 Mass. 49, 29 N.E.2d 555 (1940); Developments in the Law-Res Judicata, 65 Harv. L. Rev. 818, 846.

(2) Where the unsuccessful party cannot, for some procedural reason, appeal the matter decided against him, it may not be used as an estoppel. Scott, Collateral Estoppel by Judgment, 56 HaRv. L. REv. 1, 15 (1942).

(3) The facts must be "ultimate" in the second suit. Evergreens v. Nunan, 141 F.2d 927 (2d Cir.), cert. denied, 223 U.S. 720 (1944); see note 87 infra.

It is to be noted that the above qualifications apply only to collateral estoppel; there can be a merger or bar no matter how inadequate the first action might have been.

60 The quantity of documents, testimony, and exhibits in a major antitrust action is frequently staggering. See McAllister, The Big Case: Procedural Problems in Antitrust Litigation, 64 HARv. L. REv. 27, 32 (1950).

70 See FrD. R. Crv. P. $\$ \S 26-37$.

71 See 1 Barron \& Holtzoff, Federat, Practice \& Procedure \$ 9 at 44 (Rules ed. 1960).

72 See text accompanying note 67 supra.

73 See, e.g., Gerarcy, Inc. v. Hoover, 133 F.2d 25 (D.C. Cir. 1942). But see id. at 29-34 (dissenting opinion). The view of the Restatement originally was that collateral estoppel should not apply here. RestatenIENT, JUdGMENTs $\$ 71$, comment $d$ (1942). This was revised in light of a number of contrary cases. RESTATEMIENT OF THE LAW (Supp. 1948 at 343-44). 
be, since the proceedings are of a summary nature, with highly informal procedures. ${ }^{74}$ Similarly, where the first action was brought in a court of limited subject matter jurisdiction, the inquiry appears to be concerned with the nature of the inferior tribunal. ${ }^{75}$ Where the court in the second action is convinced that the inferior court was competent to adequately adjudicate the issue, the inferior court's determination will be conclusive in the second suit. ${ }^{70}$ Significantly, the court in Lyons v. Westinghouse quoted with approval the following statement from United States $v$. Silliman, ${ }^{77}$ a himited jurisdiction case: "Such a rule of public policy [collateral estoppel] must be watched in its application lest a blind adherence to it tend to defeat the even firmer established policy of giving every litigant a full and fair day in court."78

Moreover, the award of treble damages is two-thirds pumitive. To pernit the finding of the state court to form the basis of a subsequent action for treble damages would magnify its importance by an inordinate amount. It would tend to discourage the adjudication of legitimate controversies by imposing the threat of an antitrust defense that could, if sustained, blossom into a suit for treble damages. ${ }^{79}$ The results could be bizarre: a suit for an insignificant sum could become a vigorous lawsuit, with both parties keenly aware of the higher stakes beyond the confines of the state courtroom.

The procedural peculiarities and problems of antitrust litigation are not the sole factors which justify a rule of immunity. Attention should be paid to the policies which underlie the antitrust laws themselves. The action for treble damages, part of a comprehensive scheme of economic regulation, was designed to encourage civil enforcement of the antitrust laws. If a determination by a state court rejecting an antitrust defense were given estoppel effect, the number of potential citizens who could assist in the enforcement of the antitrust laws would be reduced. ${ }^{80}$ Because of this strong federal interest, combined with the desirability of uniform interpretation and enforcement of the antitrust laws which have a national economic impact, the rejection of collateral estoppel in such cases seems justified. ${ }^{81}$

74 Sanderson v. Niemann, 17 Cal. 2d 563, 110 P.2d 1025 (1941).

75 See Developments in the Lar-Res Judicala, 65 HARv. L. REv. 818, 849 (1952).

70 Compare United States v. Silliman, 167 F.2d 607 (3d Cir.), cert. denied, 335 U.S. 825 (1948) (collateral estoppel effect given), with Loomis v. Loomis, 288 N.Y. 222, 42 N.E.2d 495 (1942) (collateral estoppel rejected). An amnsing illustration of the sceptical scrutiny the prior finding, and the competency of the court which rendered it, may undergo is found in the reports of the Privy Council: "[A]lthough it may be desirable to put an end to hitigation, the inefficiency of many of the Indian Courts makes it advisable not to be too stringent in preventing a litigant from proving the truth of his case." Misir Rayhobardial v. Rajah Sheo Raksh Simgh, L.R. 9 Indian App. 197, 204 (1882). See also Annot., 147 A.L.R. 196 (1943).

77167 F.2d 607 (3d Cir. 1948).

${ }^{78}$ Lyons v. Westinghouse Elec. Corp., 222 F.2d 184, 189 (2d Cir.), cert. denied, 350 U.S. 825 (1955), quoting from United States v. Silliman, supra note 77.

79 Conversely, the defendant in an action brought in a state court might be reluctant to interpose the defense of illegahity through a violation of the antitrust laws, if the findings from the first action could be given preclusive effect in a subsequent antitrust suit. If the forum in which the first action is brought does not have liberal discovery procedures, the defendant could be placed at a serious disadvantage. defense.

80 Admittedly, this argument applies ouly where the state court rejects the antitrust

81 The emphasis on the uniquely strong federal interest in antitrust litigation may overstate the point. In the patent cases, and, to a somewhat lesser extent, in the Rule 10b-5 cases, the federal interest is by no means minimal. The grant of a patent confers a technical monop- 
Although discrepancies in state court application could be corrected by Supreme Court review in the exercise of its power to issue writs of certiorari, ${ }^{82}$ the court in Lyons $v$. Westinghouse felt this to be an inadequate protection, since the burden on the litigants would be great, ${ }^{83}$ and the grant of certiorari discretionary. ${ }^{84}$

On the other hand there is some indication that antitrust suits are employed as retaliatory devices by defendants in state court actions. ${ }^{85}$ Confronted with the threat of an adverse judgment for treble damages, a long and burdensome litigation, and the expenses of responding to the antitrust claimant's demands for discovery, the plaintiff in the state action might well be compelled to settle his case. The rule of Lyons $v$. Westinghouse, unfortunately, aids in making this device more effective. Assuming that the antitrust claim is frivolous and brought solely for retahatory purposes, a finding of the state court rejecting it would, if given estoppel effect, put an end to the action for treble damages. In this instance, the defendant in the state action would have little bargaining power, since his antitrust claim would be hikely to be short-lived. As a result of the rejection of collateral estoppel in Lyons v. Westinghouse, the antitrust claimant is virtually assured a trial on the merits in federal court, whatever the state court's findings.

Furthermore, since the result of a rejection of collateral estoppel is likely to be a duplication of litigation, the complexity of antitrust suits, mentioned above as tending to compel a rule of immunity, imposes a substantial burden on both the hitigants and the judicial system. Were this the only consideration, collateral estoppel would seem compelling here.

No complete rebuttal of these points is possible. To what extent the antitrust laws are used to harass adversaries is difficult to ascertain. Misuse of legal remedies and procedures is possible in a variety of ways, the number being limited only by the imagination of counsel. Whatever the abuses, however, they are not likely to be cured by the use of collateral estoppel. As to the burden of double litigation, this must be balanced against the importance of insuring that the antitrust question be given a fair hearing by a qualified judge, with the benefit of the procedures necessary to insure an adequate litigation. In the final analysis, the convenience of the litigants, and even of the judiciary, must be a secondary consideration.

Assuming, then, the desirability of a policy of federal immunization from state

oly on its holder, Zachos v. Sherman-Wiliams Co., 166 F.2d 79 (5th Cir. 1948), the result of which may have a significant economic impact. As a result, the suspension of collateral estoppel may be warranted. Cf. Bros. Inc. v. W. E. Grace Mfg. Co., 320 F.2d 594 (5th Cir. 1963). The RESTATEMENT, JUDGMENTS $\$ 71$, comment $c$ (1942) suggests a rule of immunity for patent cases. But Vanderveer v. Erie Malleable Iron Co., 238 F.2d 510 (3d Cir. 1956), cert. denied, 353 U.S. 937 (1957), discussed in text at notes 28-37 supra, appears to have settled the matter as to patent cases, having given the matter a thorough examination.

8262 Stat. 929 (1948), 28 U.S.C. \& 1257. Cf. Bruces Juices v. American Can Co., 330 U.S. 743 (1947).

83 This point is not particularly persuasive, since relitigation of the antitrust question is not likely to be any less hurdensome.

${ }^{84}$ Lyons v. Westinghouse Elec. Corp., 222 F.2d 184, 191 (2d Cir.), cert. denied, 350 U.S. 825 (1955).

85 This was the view of the trial judge in Lyons; see Lyons v. Westinghouse Elec. Corp., 16 F.R.D. 384, 385 (S.D.N.Y. 1954). This opinion was shared by the dissenting judge in the court of appeals decision. 222 F.2d at 193 (dissenting opinion). See Macli-Tronics v. Zirpoli, 316 F.2d 820, 836 (9th Cir. 1963) (dissenting opinion) (suggesting that the federal court was being "used" hy the antitrust claimant who was the defendant in a pending action in state court). 
court determinations in antitrust cases, such a rule must not be confined to prior findings of mixed law and fact; determinations of "pure fact," too, should be denied collateral estoppel effect in a subsequent antitrust action. Such a view, while supported by the reasoning of the court in Lyons v. Westinghouse, is contrary to Judge Hand's dictum contained in the denial of the petition for rehearing. It will be remembered that he felt that Becher v. Contoure Laboratories compelled the conclusion that pure determinations of fact would work an estoppel. This conclusion was unnecessary. In Becher, the state court determination was based on a question of "state law"- whether Becher had violated a confidential relationship and appropriated Oppenheimer's invention for his own use. This is to be contrasted with cases such as Lyons v. Westinghouse in which the state court finding is based upon federal law, the enforcement of which is reserved for the federal courts. By distinguishing Becher in this manner, rather than on the nature of the findings, there would have been no need to narrow the scope of the immunity in any siguificant manner; only determinations of local law would be binding on subsequent antitrust actions brought in federal court. This is entirely acceptable; in such instances, it must be presumed, state courts are competent to decide matters arising under local law. This presumption is not compelled where the question is one which has been expressly denied to the state courts.

It must be conceded that while on this basis Becher can be distinguished from Lyons v. Westinghouse, Vanderveer v. Erie Malleable Iron Co. cannot. Here the state court's determination concerned the scope of a patent-clearly a "federal" question. This, and other cases decided since Lyons v. Westinghouse, have made it quite clear that in other areas of exclusive jurisdiction, collateral estoppel will be apphed. Since the rule of immunity in antitrust cases, at least as to determinations of mixed law and fact, is still good law, ${ }^{86}$ Judge Hand's reservation as to estopping pure determinations of fact may properly be disregarded. Two distinct lines of cases have developed, and only in the antitrust cases has immunity been adopted. The other hine, the patent cases, beginning with Becher and ending with Vanderveer, permits an estoppel as to findings of fact, or mixed law and fact. No court has been confronted with a state court finding of pure fact urged as an estoppel in an antitrust action, but it appears that in this event, Judge Hand's reservation would be disregarded.

Such a course would seem warranted. Orthodox collateral estoppel makes no distinction between findings of fact and of mixed law and fact. In ascertaining the scope of plaintiff's patent, the state court in Vanderveer made a determination commonly described as a conclusion of mixed law and fact; the federal court gave it estoppel effect. In addition, such a distinction is a tenuous one at best, frequently very difficult to draw. A rule of complete immunity would avoid the necessity of determining whether the findings were of a purely factual nature; the assertion of collateral estoppel could be rejected at the threshold of the antitrust litigation. In this way, full effect can be given the policies which the rule of

${ }^{86}$ No court has suggested that the rule of immunity ought to be discarded. The only shadow cast upon its validity was the decision in Mach-Tronics v. Zirpoli, 316 F.2d 820, 832 (9th Cir. 1963) (alternative holding), in which the court refused to decide whether there was an estoppel. See text accompanying note 20 supra. However, the court suggested no reason why the rule of Lyons $v$. Westinghouse might not be followed; probably the court's uncertainty is explained by the fact that there was no way of ascertaining whether the state court finding would be one of mixed law and fact, or of pure fact. See text accompanying note 21 supra. 
immunity would serve. Should a finding by a state court be made pertaining to a claim arising under state law, however, it could be given estoppel effect in a subsequent antitrust action. ${ }^{87}$ In this manner, the exclusive jurisdiction of the federal courts in cases arising under the antitrust laws can be be preserved without materially altering the sensitive relationship between federal and state courts.

Jerome B. Falk, Jr.

87 Since the doctrine of inmunity rests, in large part, on the notion that questions pertaining to the antitrust laws might not be adequately hitigated in a state court, granting estoppel effect to a state court finding simply because it was made pertaining to a claim arising under state law would, at first, appear to undercut the inmunity in much the same fashion as did the dictum in Lyons. The justification for such an approach is twofold. Firstly, the dehicate relationship between federal and state courts would seem to require that the federal courts give conclusive effect to findings of state courts where made pursuant to claims under state law; the presumption of lack of competence, appropriate procedures, etc., would be inappropriate in such a case. Secondly, it is unlikely that such a finding would have relevance in a subsequent treble damage action; this is particularly so in hight of the requirement that the facts be "ultimate" in the second action. Evergreens v. Nunan, 141 F.2d 927 (2d Cir.), cert. denied, 323 U.S. 720 (1944). See also ReSTATEMrent, JudgMents \& 68, comment $p$ (Supp. 1948). The purpose of the formulation is to msure that the prior litigation was full and vigorous, see note 68 supra and accompanying text. It presupposes that only where the facts are "ultimate" in the second action can their use be foreseen at the time of their litigation in the first. But see Developments in the Law-Res Judicata, 69 HARv. L. REv. 818, 842-43 (1952) (suggesting that this could be more suitably achieved by other means). This rule clearly limits the application of collateral estoppel. It is also widely held that determinations used as collateral must have been ultimate in the first action. See, e.g., Yates v. United States, 354 U.S. 298, 338 (1957). But see Hinchey v. Sellers, 7 N.Y.2d 287, 165 N.E.2d 156 (1959). 